\title{
Evolution of Mitochondrial Malate Dehydrogenase in Birds (II)*
}

\author{
Ryozo Kakizawa**, Nagahisa Kuroda** and Seiitiro Utida**
}

\begin{abstract}
This is the second paper on our comparative study of electrophoretic mobility of mitochondrial malate dehydrogenase (M-MDH) in the pectoral muscle or red cells of 100 species of birds belonging to 34 families. Falconidae and Accipitridae showed the same mobility value of 140, while Cathartidae showed 100, which may suggest their terrestrial origin. In Alcidae two groups of the mobility value of 190 (Uria, Cepphus, Brachyramphus and Synthliboramphus) and 100 (Ptychoramphus, Cyclorrhynchus, Aethia and puffins) were distinctively recognized.
\end{abstract}

In our previous paper (Kuroda et al. 1982), we suggested the possibility that the values of electrophoretic mobilities of mitochondrial malate dehydrogenase (M-MDH) reflected the higher categories of avian phylogeny. The present electrophoretic study of avian M-MDH involving 15 orders, 34 families, 84 genera, 100 species and 245 individuals confirmed and extended our earlier findings.

\section{Materials and Methods}

Animals. Birds were collected from December 1981 to July 1982 from the following localities.

Birds collected in North Pacific Ocean: Fulmarus glacialis, Puffinus griseus, Puffinus tenuirostris, Uria lomvia, Synthliboramphus antiquus, Ptychoramphus aleuticus, Cyclorrhynchus psittacula, Aethia cristatella, Fratercula corniculata and Lunda cirrhata (H. Ogi). Birds collected in Hokkaido: Oceanodroma leucorhoa, Cepphus carbo, Cerorhincha monocerata (Akkeshi, July), Brachyramphus marmoratus and Sterna hirundo (Koshimizu, August) (R. Kakizawa); Mergus serrator, Bonasa bonasia (Koshimizu), Uria aalge, Aethia pusilla (Shari), Histrionicus histrionicus and Clangula hyemalis (Rausu) (M. Sekine \& H. Nakagawa); Porzana fusca and Pyrrhula pyrrhula (Hakodate).

Birds from Hahajima, Ogasawara Islands: Apalopteron familiare (H. Morioka), from South Iwo Island: Pterodroma hypoleuca and Bulweria bulwerii (Y. Tsukamoto, South Iwo Island Expedition of Environment Agency, June, 1982), from Iriomote Island: Amaurornis phoenicurus, Chalcophaps indica, Treron formosa, Motacilla cinerea, Pericrocotus divaricatus and Hypsipetes amaurotis (O. Takahashi \& M. Shoyama) and from East Ongul Island, Antarctica: Pagodroma nivea (Y. Naito).

Some other birds presented: Anser fabalis (Niigata Pref.), Actitis hypoleucos (Saitama Pref.), Anas americana, Anas fulcata, Heteroscelus brevipes and Alauda arvensis (Chiba Pref.), Limosa limosa, Stercorarius parasiticus, Sterna albifrons and Bombycilla

* Dedicated to Director Yoshimaro Yamashina, on the Occasion of the 50th Anniversary of Yamashina Institute for Ornithology.

** Yamashina Institute for Ornithology, 8-20 Nampeidai-machi, Shibuya-ku, Tokyo 150, Japan. 
japonica (Kanagawa Pref.). Blood samples were collected from birds kept in Zoos: Vultur gryphus and Bubo bubo (Nogeyama Zoo, Yokohama); Cairina moschata and Aythia fuligula (Tama Zoo, Tokyo); Cygnus atratus, Cygnus melanocoryphus, Anser anser, Anser caerulescens, Branta leucopsis, Chlorophaga picta and Plectropterus gambiensis (Inokashira Zoo, Tokyo). Other bird species given in Table 1 were obtained from dealers.

Electrophoresis. Samples of hemolysates or exudates from the frozen pectoral muscle were subjected to starch-gel electrophoresis at $\mathrm{pH}$ 7.0. The procedures used for electrophoresis and the detection of $\mathrm{M}-\mathrm{MDH}$ mobilities were reported in the previous paper (Kuroda et al. 1982).

\section{Results and Discussion}

The relative values of $\mathrm{M}-\mathrm{MDH}$ mobilities are shown in Table 1.

Procellariiformes. Previously only two species of Procellariidae had been tested. Further 5 genera, 5 species (and 1 duplicate species*) were tested, with 1 species of Hydrobatidae. All these species showed the M-MDH mobility of 100.

Podicipedidae. Only one species had been tested previously, which showed the mobility of 100 . This value for this family was confirmed by an additional species, Podiceps cristatus.

Ardeidae. Previously 10 species of 7 genera all showed the M-MDH mobility of

Table 1. Relative electrophoretic mobility of $\mathrm{M}-\mathrm{MDH}$ in pectoral muscle $\left(^{*}\right)$ or red cells of various avian species.

\begin{tabular}{|c|c|c|c|}
\hline & $\begin{array}{l}\text { Relative } \\
\text { mobility }\end{array}$ & & $\begin{array}{l}\text { Relative } \\
\text { mobility }\end{array}$ \\
\hline Procellariidae & & Uria aalge $(1)^{*}$ & 190 \\
\hline Fulmarus glacialis $(3)^{*}$ & 100 & Cepphus carbo (5)* & 190 \\
\hline Pagodroma nivea $(1)^{*}$ & 100 & Brachyramphus marmoratus (5)* & 190 \\
\hline Pterodroma hypoleuca (3)* & 100 & Synthliboramphus antiquus (5)* & 190 \\
\hline Bulweria bulwerii $(10)^{*}$ & 100 & Ptychoramphus aleuticus (1)* & 100 \\
\hline Puffinus griseus $(6)^{*}$ & 100 & Cyclorrhynchus psittacula $(2)^{*}$ & 100 \\
\hline Puffinus tenuirostris (4)* & 100 & Aethia cristatella $(6)^{*}$ & 100 \\
\hline Hydrobatidae & & Aethia pusilla (3)* & 100 \\
\hline Oceanodroma leucorhoa $(5)^{*}$ & 100 & Cerorhinca monocerata (5)* & 100 \\
\hline Podicipedidae & & Fratercula corniculata $(6)^{*}$ & 100 \\
\hline Podiceps cristatus $(1)^{*}$ & 100 & Lunda cirrhata $(6)^{*}$ & 100 \\
\hline Ardeidae & & Columbidae & \\
\hline Ixobrychus eurhythmus (1)* & 150 & Streptopelia risoria (1) & 140 \\
\hline Cathartidae & & Streptopolia tranquebarica (1) & 140 \\
\hline Vultur gryphus (2) & 100 & Macropygia phasianella (1) & 140 \\
\hline Accipitridae & & Chalcophaps indica $(5)^{*}$ & 140 \\
\hline Circus aeruginosus $(1)^{*}$ & 140 & Geopelia striata (1) & 190 \\
\hline Accipiter nisus (1)* & 140 & Zenaida aurita (1) & 140 \\
\hline Buteo lineatus (1) & 140 & Columbina cruziana (2) & 140 \\
\hline Spizaetus nipalensis $(1)^{*}$ & 140 & Gallicolumba luzonica $(1)^{*}$ & 220 \\
\hline
\end{tabular}


Table 1. (continued)

\begin{tabular}{|c|c|c|c|}
\hline & $\begin{array}{l}\text { Relative } \\
\text { mobility }\end{array}$ & & $\begin{array}{l}\text { Relative } \\
\text { mobility }\end{array}$ \\
\hline Falconidae & & Gallicolumba xanthonura (1) & 140 \\
\hline Falco tinnunculus $(1)^{*}$ & 140 & Treron formosae (2)* & 140 \\
\hline Falco subbuteo (1)* & 140 & Ducula aenea $(1)^{*}$ & 140 \\
\hline Falco rusticolus (1)* & 140 & Ducula bicolor (2) & 140 \\
\hline Anatidae & & Psittacidae & \\
\hline Cygnus atratus (5) & 100 & Neophema bourkii (1) & 360 \\
\hline Cygnus melanocoryphus (5) & 100 & Psittacus erithacus (2) & 360 \\
\hline Anser fabalis $(1)^{*}$ & 100 & Agapornis fischeri (2) & 320 \\
\hline Anser anser (2) & 100 & Cuculidae & \\
\hline Anser caerulescens (3) & 100 & Cuculus fugax (1)* & 200 \\
\hline Branta leucopsis (3) & 100 & Strigidae & \\
\hline Chloephaga picta (3) & 100 & Bubo bubo (2) & 200 \\
\hline Plectropterus gambiensis (2) & 100 & Ketupa ketupu (1) & \\
\hline Cairina moschata (5) & 100 & Strix aluco $(1)^{*}$ & 200 \\
\hline Anas americana (2) & 100 & Bucerotidae & \\
\hline Anas falcata (2) & 100 & Buceros bicornis (1)* & 200 \\
\hline Aythya baeri (1)* & 100 & Ramphastidae & \\
\hline Aythya fuligula (14) & 100 & Ramphastos toco $(1)^{*}$ & 250 \\
\hline Histrionicus histrionicus $(1)^{*}$ & 100 & Eurylaimidae & \\
\hline Clangula hyemalis (1)* & 100 & Calyptomena viridis (1) & 360 \\
\hline Mergus serrator $(1)^{*}$ & 100 & Alaudidae & \\
\hline Phasianidae & & Alauda arvensis $(1)^{*}$ & 360 \\
\hline Meleagris gallopavo (3) & 100 & Motacillidae & \\
\hline Bonasa bonasia $(1)^{*}$ & 100 & Motacilla cinerae $(1)^{*}$ & 360 \\
\hline Alectoris chukar (4) & 100 & Campephagidae & \\
\hline Excalfactoria chinensis (2) & 100 & Pericrocotus divaricatus (1)* & 360 \\
\hline Bambusicora thoracica (1) & 100 & Pycnonotidae & \\
\hline Lophura nycthemera (3) & 100 & Hypsipetes amaurotis (2) (2)* & 340 \\
\hline Chrysolophus pictus (3) & 100 & Irenidae & \\
\hline Chrysolophus amherstiae (4) & 100 & Chloropsis cochinchinensis $(6)^{*}$ & 360 \\
\hline Pavo cristatus (4) & 100 & Bombycillidae & \\
\hline Pavo muticus (1) & 100 & Bombycilla japonica (1) & 360 \\
\hline Rallidae & & Muscicapidae & \\
\hline Porzana fusca (1)* & 100 & Saxicola torquata $(1)^{*}$ & 360 \\
\hline Amaurornis phoenicurus $(1)^{*}$ & 100 & Garrulax canorus $(2)$ & 360 \\
\hline Charadriidae & & Paridae & \\
\hline Vanellus indicus $(2)^{*}$ & 100 & Parus major (1)* & 360 \\
\hline Scolopacidae & & Meliphagidae & \\
\hline Limosa limosa (1) & 200 & Apalopteron familiare (1)* & 360 \\
\hline Actitis hypoleucos $(1)^{*}$ & 250 & Fringillidae & \\
\hline Heteroscelus brevipes (12) & 250 & Pyrrhula pyrrhula (1)* & 360 \\
\hline Stercorariidae & & Coccothraustes migratorius (1) & 360 \\
\hline Stercorarius parasiticus $(1)^{*}$ & 100 & Sturnidae & \\
\hline Laridae & & Scissirostrum dubium (1) & 360 \\
\hline Sterna hirundo (2)* & 100 & Corvidae & \\
\hline Sterna albifrons (1) & 100 & Pyrrhocorax pyrrhocorax (1)* & 360 \\
\hline \multicolumn{4}{|l|}{ Alcidae } \\
\hline Uria lomvia (4)* & 190 & & \\
\hline
\end{tabular}

The numbers in parenthesis indicate the number of individuals examined. 
150 and an additional species (duplicate genus*) tested gave the same value.

Falconiformes. So far 6 species of 6 genera of Accipitridae all had showed the mobility value of 140 . This was confirmed by 4 additional species ( 1 new and 3 duplicate genera). Three species of Falco tested in the present study also had the mobility value of 140. This is of interest because it suggests that Falconidae and Accipitridae may be more closely related than are generally considered. The Cathartidae, on the other hand, may be a distinct and probably a primitive group, since two individuals of Vultur gryphus showed the M-MDH mobility of 100 , which we think is the basic or primitive value, shown by terrestrial and aquatic bird groups. Therefore, Cathartidae is considered to be of terrestrial origin from which other Falconiform families may have evolved, and some fossil species, such as Neocathartes, could be said to suggest the remote connection with Ciconiiformes. The Accipitridae, at a high position in Fig. 4 of our previous paper, should be shifted to a lower position next to Ciconiiformes and arranged through Cathartidae (100) to Accipitridae (140) and Falconidae (140). Such relationships of Falconiformes with aquatic bird groups are implicit in the recent phylogenetic discussions on the biochemical (Sibley 1982) or ecop-hysiological (cf. Feduccia 1980) basis.

Anatidae. All the 16 additional species (5 new and 6 duplicate genera) showed the mobility value of 100 , as in 29 species tested earlier.

Phasianidae. All the 10 additional species ( 7 new and 1 duplicate genera) showed the mobility value of 100 , as in 17 species tested earlier.

Rallidae. Two additional genera and species showed the mobility value of 100 as in one species tested earlier.

Charadriidae. One species of Charadrius earlier showed the value of 100 and this was confirmed by one species of Vanellus.

Scolopacidae. In the previous data, Tringa, Xenus, Arenaria, Phalaropus and Calidris showed the M-MDH mobility of 250, with the exception of 100 in Numenius phaeopus. This time, we added Actitis hypoleucos and Heteroscelus brevipes (12 birds) to the mobility value of 250 , while Limosa limosa showed the value of 200 . Numenius and Limosa are large-bodied genera with distinct foraging habits and adaptive bill shape. It is of interest to conjecture that their low $\mathrm{M}-\mathrm{MDH}$ mobility values might reflect some ecophysiological correlations or older (primitive) phylogenetical origin.

Stercorariidae. This is a newly tested family, represented by Stercorarius parasiticus, which showed the mobility value of 100 .

Laridae. So far, 2 genera 6 species had showed the mobility of 100 . One new genus and 2 species Sterna albifrons and $S$. hirundo were added to this list.

Alcidae. So far, one species Synthliboramphus antiquus had been tested, showing the mobility value of 190 . This value was confirmed with 5 individuals of the same species, as well as with large bodied Uria lomvia and $U$. aalge, middle-sized Cepphus carbo and small-sized Brachyramphus marmoratus. The other small to middle-sized species, Ptychoramphus, Cyclorrhynchus, Aethia (cristatella and pusilla), Cerorhinca, Fratercula (corniculata) and Lunda, all showed the mobility of 100. This clear grouping

\footnotetext{
* Duplicate genus or species means the genus or species used both in previous and present studies.
} 
well fit the Ogilvie-Grant's (1898) basic classification: Alcinae-Feathering on the lores extending at least to the posterior border of the nasal opening which is exposed or overhung by feathers, and Fraterculinae-Feathering on the lores not extending to the posterior border of the nasal opening, which is overhung by a horny scale. This grouping is also supported osteologically; Alcinae having a long sternum, with short clavicles, and Fraterculinae a shorter sternum, with developed clavicles and with posterior plate (Kuroda 1954). The only exception is Cepphus which was confirmed to be Alcinae species by M-MDH. Osteologically Cepphus resembles to Fraterculinae type (Kuroda 1955). This may be attributed to its adaptational deviation from Alcinae group in its food habits and breeding activity.

Columbidae. So far, 4 genera and species had showed the mobility value of 140 , with the exception of 190 in Geopelia cuneata. In the new tests, Geopelia striata showed the mobility of 190 while Gallicolumba luzonica had 220 and 10 other species (6 new and 2 duplicate genera), including Gallicolumba xanthonura, had 140.

Psittacidae. The very high M-MDH mobility of 300-360 in parrots have been discussed in the previous paper. Three species (Psittacus and duplicate genera Neophema and Agapornis) were added in the present study.

Cuculidae and Strigidae. In Cuculidae, Cuculus fugax was added to two other congeneric species so far tested, all showing the mobility of 200. In Strigidae, 3 species Ketupa ketupu, Bubo bubo and Strix aluco (duplicate genus) was added, showing the value of 200 as in the other species already examined (Otus showing only 130).

Bucerotidae. This is a new family to be tested. Buceros bicornis showed the mobility value of 200. However, related Alcedinidae marked 220 and 250, and Coraciidae 220.

Ramphastidae. Previously Ramphastos sulfuratus showed the mobility value of 230, while the newly tested congeneric species $R$. toco marked 250.

Passeriformes. All the Passeres species previously tested had showed the value of 360 which was confirmed by 13 families ( 4 duplicate families), but only in Pycnonotidae (Hypsipetes amaurotis) the value of 340 was obtained.

In conclusion, some of the results confirmed our previous view with similar data of additional species, but in some groups, such as Falconiformes, Scolopacidae, Alcidae, Bucerotidae and Ramphastidae, new data proved to be useful for deducing phylogenetic history or to elucidate adaptive radiation among taxa.

\section{Acknowledgements}

The authors wish to express hearty thanks to many people for collecting bird specimens and blood samples; i.e. Prince Hitachi, Cancer Institute, Tokyo; Dr. H. Ogi, Research Institute of North Pacific Fisheries, Hokkaido University; Dr. Y. Naito, National Institute of Polar Research; Mr. K. Nakamura, Kanagawa Prefectural Museum; Mr. H. Nakagawa, Shiretoko Museum, Hokkaido; Mr. T. Kazama, Nature Protection Section, Life Environment Division, Niigata Pref.; Messrs. H. Hori and Y. Osaka, Nogeyama Zoological Garden in Yokohama; Mr. M. Saito, Tokyo Tama Zoological Park; Mr. H. Sugiura, The Aquarium of Inokashira Park Zoo; (Mr. \& Mrs. 
Y. Hasuo, Gyotoku Bird Observatory, Chiba Pref.; Mr. N. Yanagisawa, Japan Association of Preservation of Birds; Mr. Y. Tsukamoto, Wild Bird Society of Japan; Mr. O. Takahashi, Sendai; Mr. M. Shoyama, Iriomote Island; Mr. M. Sekine, Koshimizu-cho, Hokkaido; Mr. S. Imai, Imai Stuff Shop; Mr. T. Ishihara, Ishihara Animals and Birds Co., Mr. T. Kohno, Keihin Choju Trading Co., Mr. S. Shimizu, Peru Aquarium Co., and Messrs. K. Ozaki and A. Sasagawa in our Institute. We also thank Professor J. Kikkawa, Zoology Department, The University of Queensland for reading the manuscript, and Mrs. H. Suwa for her assistance.

\section{References}

Feduccia, A. 1980. The Age of Birds. Harvard Univ. Press, 196 pp.

Kuroda, N. 1954. On some osteological and anatomical characters of Japanese Alcidae (Aves). Jap. J. Zool. 11: $311-327$.

Kuroda, N. 1955. Additional notes on the osteology of Alcidae (Aves). Annot. Zool. Japon. 28: 110-113.

Kuroda, N., Kakizawa, R., Hori, H., Osaka Y., Usuda, N. \& Utida, S. 1982. Evolution of mitochondrial malate dehydrogenase in birds. J. Yamashina Inst. Ornith. 14: 1-15.

Ogilvie-Grant, W. R. 1898. Order Alcae. In Cat. Birds Brit. Mus. 26: 559-622.

Sibley, C. G. 1982. Personal communication. 